\title{
Differences in Self-Perception and School Adjustment According to Time-Use Profiles of Adolescents with Chronic Diseases
}

\author{
Boram Lee \\ Department of Child Development \& Family Studies, Seoul National University, Seoul, Korea \\ 만성질환을 가진 청소년의 생활시간 활용 유형에 \\ [다른 집단별 자아인식과 학교생활적응의 차이 \\ 이보람 \\ 서울대학교 아동가족학과
}

Objective: This study aims to classify groups according to the time-use profiles of adolescents with chronic diseases and identify differences in self-perception and school adjustment by group.

Methods: The study made used data from the fifth wave of Korean Children and Youth Panel Survey. Among 2,351 adolescents, 958 (40.7\%) with chronic diseases were analyzed using LPA and MANCOVA.

Results: As a result of LPA, four groups were classified according to time-use profiles of adolescents with chronic diseases: media using leisure type (13.5\%), private education dependent learning type (63.2\%), self-study learning type (7.7\%), and balanced leisure type (13.5\%). MANCOVA results showed significant differences in the level of self-perception and school adjustment according to time-use profiles, even after controlling for demographic variables that may have an effect. Adolescents in the self-study learning type, specifically, tended to set a clear goal of life based on their self-identity and were well adapted to school life.

Conclusion: Findings suggest that profiles of time-use may affect self-perception and school adjustment in adolescents with chronic diseases. These results indicate that it is important for chronically ill adolescents to have more meaningful experiences in daily life to develop resiliency. Therefore, various opportunities and supportive environments should be provided to adolescents with chronic diseases to spend their time in a healthier way, evaluating themselves positively and perceiving meaning in life.

Keywords: adolescents with chronic disease, time use, latent profile analysis, self-perception, school adjustment

\begin{abstract}
서론
'건강한 신체에 건전한 정신이 깃든다(A sound mind in a sound body)'라는 말이 있듯이 신체적으로 건강한 것은 심리사회적

Corresponding Author: Boram Lee, Department of Child Development \& Family Studies, Seoul National University, 1, Gwanak-ro, Gwanak-gu, Seoul, Korea

E-mail: bboram7@snu.ac.kr
\end{abstract}

건강의 전제조건으로 여겨진다. 아동에게 신체는 세상을 인식 하는 일차적 통로이며 영유아기에 이루어지는 학습과 발달 역 시 접촉과 탐색을 기반으로 이루어지기 때문에 감각기관과 운 동능력에 문제가 없고 신체적으로 건강한 것은 발달의 기초가

(c)The Korean Association of Child Studies

This is an Open Access article distributed under the terms of the Creative Commons Attribution Non-Commercial License (http:// creativecommons.org/licenses/by-nc/4.0) which permits unrestricted noncommercial use, distribution, and reproduction in any medium, provided the original work is properly cited. 
된다. 하지만 신체적으로 건강한 것이 발달의 전제조건이라는 생각은 신체적으로 건강하지 못한 아동은 정신적으로도 건강 할 수 없고 정상적인 발달을 이루지 못한다는 선입견을 형성 하여 질병을 가진 아동에 대한 부정적인 인식을 확산시켰다. 그리고 질병을 가진 아동의 발달과 적응에 대한 상당수의 연 구들 역시 이러한 부정적 선입견이 반영된 결핍중심 혹은 문 제 중심 시각(deficit/problem-centered perspectives)에서 이루어 져 왔다(Lavigne \& Faier-Routman, 1992). 이러한 시각에서 이 루어진 많은 연구들은 질병을 가진 아동과 질병이 없는 아동 을 비교하거나 질병의 종류 혹은 질병의 정도에 따라 아동들 의 발달 결과를 비교함으로서 질병이 미치는 부정적인 영향을 부각시키고 질병을 가진 아동에게 결핍된 것이 무엇인지 살펴 보았다(Barlow \& Ellard, 2006; Roder \& Boekaerts, 1999).

질병을 가진 청소년의 발달과 적응에 대해 이루어진 연구 들은 만성질환이 급격한 신체적, 심리적, 사회적 변화를 경험 하는 청소년에게 누적된 스트레스(cumulative stressors)로 작용 한다는 점을 강조한다(Hatherill, 2007). 청소년기에는 타인과 다른 자신만의 독특한 특성을 인식하고 주관과 소신을 일관 성 있게 유지하며(Erikson, 1968), 이를 바탕으로 자신의 직업 적성을 파악하고 미래에 하고 싶은 일을 결정해야한다(Suris, Michaud, \& Viner, 2004). 그리고 학교에서 보내는 시간이 많 은 시기인 만큼 학교생활에 잘 적응하는 것이 개인의 삶의 질 과 이후 성인기의 성취 및 적응에도 많은 영향을 미친다(H. Lee, Son, \& Hong, 2018). 그런데 천식, 비염, 아토피성 피부염, 비만, 당뇨병 등과 같은 만성질환은 증상과 병변이 생명에는 지장이 없지만 경과를 예측하기 어렵고 쉽게 치료되지 않는 특성을 가지고 있다. 이러한 난치성 만성질환은 꾸준한 약물 치료와 더불어 운동이나 식이요법을 통한 건강관리를 요하기 때문에 생활양식을 변화시켜야하며 질병관리의 부담이 크다 (Hatherill, 2007). 또한 수면장애나 만성피로와 같은 문제를 야 기하여 신체능력과 수행수준을 떨어뜨릴 뿐만 아니라 외모를 변화시키기 때문에 학업과 학교생활, 그리고 정체성 형성과 또래관계가 중요해지는 청소년기에 스트레스를 가중시키는 위험요인으로 작용할 수 있다(Greenberg, Kazak, \& Meadows, 1989; Rhee, Wenzel, \& Steeves, 2007; Suris et al., 2004; Taylor, Gibson, \& Franck, 2008). 그래서 상당수의 선행연구들은 만성 질환청소년들의 낮은 자존감, 부정적인 자아상, 목표 설정의 어려움, 그리고 또래관계나 학업성취의 어려움으로 인한 학 교생활의 부적응에 대해 보고하였다(Blaiss, 2008; King et al., 2005; Shiu, 2001).

하지만 최근에는 긍정심리학에 기반을 둔 많은 학자들이
청소년의 병리적이고 부정적인 측면보다는 긍정적인 측면 에 집중하여 강점과 자산을 탐색하고 그것을 증진시킬 수 있 는 방안에 대해 연구하고 있다(Cowen \& Kilmer, 2002). 이는 앞서 언급했던 결핍중심 혹은 문제 중심 시각과 반대되는 개 념으로, 강점과 자산을 중점적으로 살펴보는 다양한 시각들 (strength/asset-focused perspectives)을 포괄하는 청소년의 긍정 발달(positive youth development [PYD]) 패러다임으로 불린다 (Guerra \& Bradshaw, 2008). 청소년의 긍정발달을 지지하는 이 러한 관점은 모든 청소년이 성공적이고 건강하게 발달할 수 있는 강점과 잠재력을 가지고 있다고 믿고(Lerner, Brentano, Dowling, \& Anderson, 2002), 청소년기는 개개인이 가진 고유 한 특성, 재능, 기술, 그리고 관심사 등을 숙련시켜가는 과정에 있다는 것을 강조한다(Larson, 2000). 또한 청소년 발달의 긍정 적인 측면에 집중하면서도 발달에 부정적인 영향을 미칠 수 있는 위험요인의 존재를 부정하거나 간과하지 않는다. 다만 청소년들이 가질 수 있는 다양한 위험요인에도 불구하고 그들 이 가진 잠재력을 모두 발휘하여 건강하게 성장하고 발달해가 는 긍정적인 발달과정에 더 집중한다(Lerner \& Benson, 2003).

만성질환청소년의 경우에도, 질병으로 인해 발생하는 부 정적인 경험과 스트레스에도 불구하고 긍정적인 발달 결과를 보이는 청소년들이 있다(Spratling \& Weaver, 2012). 적응은 보 호요인과 위험요인 간의 힘겨루기라고 볼 수 있는데, 만성질 환이라는 위험요인을 가지고 있음에도 불구하고 긍정적으로 발달하는 청소년들은 자신이 가진 강점과 보호요인들을 효과 적으로 활용하여 질병으로부터 발생하는 생활양식의 변화에 유연하게 대처하고 적응한다(Atkin \& Ahmad 2001; Jenson \& Fraser, 2015). 개인이 역경에 맞닥뜨렸을 때 개인 내·외부에 있 는 보호요인을 효과적으로 활용하여 역경으로부터 발생하는 부정적인 영향력을 조절하고 완충시키며 긍정적인 결과를 도 모하게 되는 일련의 과정은 자아탄력성이라는 개념으로 설명 한다(Fergus \& Zimmerman, 2005). 자아탄력성에 대한 정의는 학자의 관점에 따라 다르게 이루어지지만, 최근에는 자아탄력 성을 개인의 능력이나 특성, 혹은 발달 결과(outcome)로 설명 하기 보다는 발달 과정(process)으로 보는 관점이 더욱 설득력 있게 받아들여지고 있다(Fergus \& Zimmerman, 2005). 그리고 이러한 과정은 청소년이 속한 환경에서 다양한 관계를 맺으며 발생하는 일상의 경험을 통해 발현된다.

만성질환을 가진 청소년들의 일상은 그들이 어떤 활동을 하면서 시간을 보내는지 살펴봄으로써 예측할 수 있다. 청소 년의 시간사용과 활동에 대한 선택은 개인의 생활양식뿐만 아 니라 그들이 접하는 생태학적 환경과 맥락을 파악하는데 유용 
한 정보를 제공한다(Larson \& Verman, 1999). 그리고 24시간 이라는 제한된 시간 자원을 활용하는 방식은 청소년기에 달 성해야 하는 과업을 수행하는데 영향을 미칠 뿐 아니라 성인 기로의 전환을 보다 수월하게 하는 중요한 발달적 경험이 된 다(Zick, 2010). 우리나라 청소년의 생활시간활용에 대한 많은 연구가 이루어져 있지만, 세 가지 측면에서 한계가 있다. 첫째, 특정 활동으로 보내는 시간의 양이 청소년의 발달에 어떠한 영향을 미치는지 탐색한 연구들이 많이 있다. 예를 들어, 수면 시간, 사교육시간, 게임이용시간, 친구와 보내는 시간 등이 청 소년의 스트레스, 우울, 공격성, 불안 등의 정서행동문제나 학 습, 기억, 주의력과 같은 인지 기능에 미치는 영향에 초점을 두 어 이루어진 연구(S. J. Kim \& Chung, 2016; J. Lee, Kang, Rhie, \& Chae, 2013; H. Park, 2015; Ryou, 2017; Ryu \& Jeong, 2001; J. Song et al., 2010)가 있다. 이러한 연구는 청소년들이 일상 속 에서 다양한 활동을 하면서 시간을 보내는데도 불구하고, 이 를 통합적으로 살펴보지 못했다는 점에서 한계가 있다. 둘째, 청소년의 평균적인 생활시간 활용 실태를 파악하고 이에 영향 을 미치는 요인을 탐색한 연구가 많다. 구체적으로, 연령이나 성별과 같은 개인의 특성, 부모의 교육수준, 가구 소득수준, 맞 벌이 여부와 같은 가족의 특성에 따라 생활시간 활용에 차이 가 있다는 연구결과(Chin, 2008; Ha, 2017; H.-J. Park, Son, \& Kim, 2017; Y.-J. Song, 2013)는 청소년이 가진 변화하지 않는 특성에 따라 생활시간 활용에 차이가 있다는 것을 밝힐 뿐 교 육적 함의를 제공하지 못한다. 그리고 마지막으로, 우리나라 청소년들의 만성질환 유병율이 높은 수준인데도 불구하고 국 내에서는 아직 만성질환을 가진 청소년의 생활시간 활용에 대 한 연구가 이루어지지 않았다. 2016년도 청소년건강행태온라 인조사(Korea Centers for Disease Control and Prevention, 2017) 에 따르면 우리나라 13-19세 청소년의 만성질환 유병율은 알 레르기비염 $35.5 \%$, 아토피성 피부염 $25.1 \%$, 비만 $12.8 \%$, 천식 $9.1 \%$ 으로 나타났다.

이 연구에서는 기존 연구의 한계를 극복하기 위하여 잠재 프로파일분석(Latent Profile Analysis [LPA])을 도입하여 만성 질환을 가진 청소년의 생활시간 활용유형을 탐색하고, 유형 에 따른 집단별 특성을 통합적으로 살펴보고자 한다. 잠재프 로파일분석은 변수들의 관계를 통해 현상을 파악하는 기존 의 변수 중심적 분석방법(variable-centered analysis)과 달리, 개 인의 특성에 관심을 가지고 접근하는 사람 중심적 분석방법 (person-centered analysis)이다. 다시 말해서, 만성질환청소년의 생활시간 활용에 대해 변수 중심적 분석방법을 적용할 경우에 는 만성질환청소년을 동질 집단으로 보기 때문에 다양하게 나
타날 수 있는 생활시간 활용 양상을 포착할 수 없다. 반면에 사 람 중심적 분석방법은 모집단 내에 개인이 가질 수 있는 이질 성을 허용하기 때문에 만성질환을 가진 청소년 집단에서 다양 하게 나타날 수 있는 생활시간 활용유형을 추정하고, 생활시 간 활용 양상에 영향을 미칠 수 있는 요인들 역시 각각의 유형 별로 다르게 작용한다는 가정을 충족시킬 수 있다(Bergman \& Magnusson, 1997). 따라서 이 연구에서 잠재프로파일분석을 도입하여 만성질환청소년의 생활시간 활용을 살펴본다면 앞 서 지적한 기존연구의 한계를 극복하여 만성질환을 가진 청소 년들의 다양한 활동에 대한 생활시간을 통합적으로 살펴보고, 만성질환 청소년들 개개인의 특성에 따라 각기 다른 시간사용 패턴을 보인다는 것을 확인할 수 있으며, 생활시간 활용 유형 에 따라 청소년기에 달성해야 할 발달과업인 자아인식과 학교 생활적응에 차이가 있는지 밝혀낼 수 있다. 이는 만성질환청 소년의 일상경험이 탄력성으로 작용하여 발달과업 달성에 긍 정적인 영향을 미치는지 실증적으로 검증하고, 만성질환청소 년을 위한 개입 방안을 마련할 때 기초가 될 만한 교육적 함의 를 도출할 수 있을 것으로 기대한다.

요컨대, 이 연구에서는 만성질환을 가진 청소년들의 생활 시간 활용 실태를 살펴 본 후, 잠재프로파일 분석결과에 따라 집단을 나누어 집단별 생활시간 활용 양상을 살펴보고자 한 다. 그리고 만성질환을 가진 청소년들이 질병에서 기인한 일 상생활과 학업의 어려움으로 인해 청소년기에 이루어야할 과 업을 달성하는데 어려움을 겪는다는 선행연구들(Greenberg et al., 1989; Hatherill, 2007; King et al., 2005; Rhee et al., 2007; Shiu, 2001; Suris et al., 2004; Taylor et al., 2008)을 바탕으로 생 활시간 활용 유형에 따라 자아인식과 학교생활적응에 차이 가 있는지 살펴보고자 한다. 또한 인구사회학적 특성이 시 간 활용에 영향을 미친다는 선행연구(Ha, 2017; Hofferth \& Sandberg, 2001; H.-J. Park et al., 2017; Y.-J. Song, 2013)를 고려 하여 생활시간 활용유형에 따라 차이가 나타나는 인구사회학 적 변인을 탐색하여 통제변인으로 설정하고자 한다. 이를 위 한 연구문제는 다음과 같다.

\section{연구문제 1}

만성질환을 가진 청소년의 생활시간 활용 실태는 어떠한가?

\section{연구문제 2}

만성질환을 가진 청소년의 생활시간 활용 유형에 따라 분류 한 집단의 수와 각 집단별 생활시간 활용 실태는 어떠한가? 


\section{연구문제 3}

만성질환을 가진 청소년의 생활시간 활용 유형에 따라 분류 한 집단의 인구사회학적 특성은 어떠한가?

\section{연구문제 4}

만성질환을 가진 청소년의 생활시간 활용 유형에 따라 나눈 집단별 자아인식과 학교생활적응의 차이는 어떠한가?

\section{연구방법}

\section{연구대상}

이 연구는 한국청소년정책연구원(NYPI; 2010-2017)에서 구 축한 한국아동청소년패널조사 (Korean Children and Youth Panel Survey [KCYPS])의 중학교 1학년 패널의 5차(2014)데이 터를 활용하여 분석하였다. KCYPS는 교육과학기술부에서 제 공하는 전국학교 일람표를 표본틀로 다단계층화집락추출법 (multi-stage stratified cluster sampling)으로 추출한 초등학교 1학 년, 초등학교 4학년, 중학교 1학년의 3 개 중다 패널을 대상으 로 2010년부터 2016년까지 추적 조사한 자료로서 한국 아동. 청소년 모집단의 대표성이 확보되며 연구결과를 일반화하기
에 유용하다.

이 연구에서는 중학교 1학년 코호트의 청소년들이 고등학 교 2학년일 때 수집된 5 차 년도 자료를 분석하였다. 시간은 누 구에게나 똑같이 24시간이 주어지는 유한한 자원이기 때문에 청소년들이 어떤 활동을 선택하고 그 활동으로 얼마나 시간을 보내는지 살펴보는 것은 그들의 생활양식을 파악하는데 도움 이 된다. 청소년기의 생활양식은 그 시기에 달성해야 하는 과 업을 수행하는데 영향을 미치기 때문에 자아인식과 학교생활 적응에 차이가 나타날 수 있다. 후기 청소년기에 해당하는 고 등학교 2학년은 청소년기에 획득해야 할 자아정체감과 진로 정체감을 어느 정도 공고화 하며, 이를 바탕으로 자신에 대해 평가하는 자아존중감을 안정적으로 유지하게 된다. 그리고 우 리나라에서 고등학교에 다니는 청소년의 경우에 입시와 진로 에 대한 스트레스가 높고, 학업과 관련된 활동으로 보내는 시 간이 매우 길기 때문에 만성질환을 가진 청소년에게는 스트레 스가 가중될 수 있다는 점에서 후기청소년기에 해당하는 5 차 년도 자료를 활용하여 분석하였다.

이 연구의 분석대상은 고등학교 2 학년 청소년 총 2,351 명 (남자청소년 1,176 명, 여자청소년 1,175 명)중 만성질환을 가 진 청소년 958명(전체 청소년의 40.7\%)이다. Table 1에 제시하 였듯이 그 중 남자청소년은 511명(53.3\%)이고 여자청소년은 447명(46.7\%)이다. 질병유형에 따르면 비염을 가진 청소년이

Table 1

Participants' Characteristics

\begin{tabular}{|c|c|c|}
\hline Variable & Group & $N(\%)$ \\
\hline \multirow{3}{*}{ Gender } & Boy & $511(53.3)$ \\
\hline & Girl & $447(46.7)$ \\
\hline & Total & $958(100.0)$ \\
\hline \multirow{9}{*}{ Type of chronic diseases } & Asthma & $76(7.9)$ \\
\hline & Rhinitis & $656(68.5)$ \\
\hline & Atopic dermatitis & $225(23.5)$ \\
\hline & Obesity & $260(27.1)$ \\
\hline & Heart disease & $16(1.7)$ \\
\hline & Diabetes & $7(0.7)$ \\
\hline & etc & $97(10.1)$ \\
\hline & Total(multiple responds) & $1,337(139.6)$ \\
\hline & More than 2 diseases & $278(29.0) / 958(100.0)$ \\
\hline \multirow{4}{*}{ Extent of chronic diseases } & Never disturbed & $267(27.9)$ \\
\hline & Having some difficulties & $498(52.0)$ \\
\hline & A lot of difficulties & $193(20.1)$ \\
\hline & Total & $958(100.0)$ \\
\hline
\end{tabular}


656명(68.5\%)으로 가장 많았고, 비만 260명(27.1\%), 아토피성 피부염 225명(23.5\%), 기타 97명(10.1\%), 천식 76명(7.9\%), 심 장병 16 명 $(1.7 \%)$, 당뇨병 7 명 $(0.7 \%)$ 이다. 이중 두 가지 이상 의 질병을 중복으로 가지고 있는 청소년은 278 명으로 질병을 가진 전체 청소년 중 $29.0 \%$ 였다. 자신이 가진 질병이 학업이 나 일상생활에 얼마나 지장을 주는지 묻는 문항에 대해 498명 (52.0\%)이 질병이 학업이나 생활에 약간의 어려움을 준다고 응답하였고, 267명(27.9\%)이 전혀 지장을 주지 않는다, 193명 (20.1\%)이 매우 많은 어려움을 준다고 응답하였다.

\section{연구도구}

\section{청소년의 만성질환}

청소년의 만성질환은 4차 년도에 청소년용 설문지를 통해 조 사되었다. 천식, 비염, 아토피성 피부염, 비만, 심장질환, 당뇨 병, 기타질환에 대해 각각 '질병이 있다', '질병이 없다'로 응답 한 자료를 바탕으로 한 가지 이상의 항목에 질병이 있다고 응 답한 청소년을 추출하였다. 질병이 있다고 응답한 경우에는 질병이 학업이나 일상생활에 얼마나 지장을 주는지를 추가로 물어보았는데, '전혀 없다', ‘약간', '많이'의 3범주로 답하도록 하였다. 이는 질병의 정도로 해석할 수 있어서 이 연구에서는 '전혀 없다'는 '경증', '약간'은 ‘중등증', '많이'는 '중증'으로 재 범주화하여 활용하였다. 질병의 중증도나 상태는 질병의 유 무보다도 청소년의 적응(Eiser, 1990)이나 발달 결과(La Greca, 1990)에 많은 영향을 미칠 수 있다는 선행연구를 고려하여 질 병의 정도를 반영하였다.

\section{청소년의 생활시간}

KCYPS 5차년도 조사는 청소년의 취침시간, 기상시간, 학원/ 과외시간, 학교숙제시간, 학원/과외숙제시간, 기타공부시간, 독서시간, 컴퓨터/게임기 오락시간, TV/비디오 시청시간, 친 구들과 노는 시간에 대한 열 가지 생활시간 자료를 포함하고 있다. 이 연구에서는 이 열 가지 생활시간을 바탕으로 여섯 가 지 범주의 시간으로 재분류한 후, 생활시간에 따른 집단유형 을 분류하기 위하여 잠재프로파일 분석을 실시하였다. 첫 번 째로 취침시간과 기상시간 정보를 활용하여 수면시간을 계산 하였고, 두 번째로 학원/과외시간, 학원/과외숙제시간으로 사 교육시간을 계산하였다. 세 번째로 학교숙제시간, 기타공부시 간으로 개인공부시간을 계산하였다. 네 번째는 독서시간 변수
를 그대로 활용하고, 다섯 번째는 매체이용시간으로 컴퓨터/ 게임기 오락시간과 TV/비디오 시청시간을 더하여 변수를 생 성하였다. 마지막 여섯 번째는 친구들과 노는 시간을 그대로 활용하였다. 이 여섯 범주의 시간은 모두 주중, 주말 시간으로 각각 두 개의 시간정보를 가지고 있어서 총 열두 개의 변수로 이루어져 있고, 분 단위로 코딩하였다.

\section{자아인식}

자신에 대한 인식은 인지적인 지각과 평가를 포괄한다. 이 연 구에서는 자신에 대한 인지적인 자각을 의미하는 자아정체감 과 진로정체감, 그리고 자신에 대한 주관적인 평가인 자아존 중감으로 자아인식 수준을 살펴보았다.

KCYPS에서 자아정체감은 H.-O. Song (2008)이 개발한 척 도를 수정·보완하여 측정하였고 뚜렷한 삶의 목표, 주관과 소신에 대한 8 문항으로 구성되어 있다. 진로정체감은 Kong (2008)가 개발한 척도로 측정하였고 미래에 하고 싶은 일, 직 업적성파악 등에 대한 8문항으로 구성되어 있다. 마지막으로 자아존중감은 Rosenberg (1965)의 척도를 사용하여 측정하였 고, 총 10 문항에 대해 4점 리커트 척도로 응답하도록 구성되 어있다. 부정적 자존감의 5 개 문항은 역산처리 하여 점수가 높 을수록 자아존중감이 높다고 해석할 수 있다. 자아인식 척도 의 신뢰도계수(Cronbach's $\alpha$ )는 전체 .887이며 하위요인별로 는 자아정체감 .667 , 진로정체감 .882 , 자아존중감 .840 로 양호 한 수준이었다.

\section{학교생활적응}

학교생활적응은 $\operatorname{Min}$ (1991)가 초등학생용으로 제작한 척도를 수정·보완하여 측정하였다. 학교생활적응의 하위요인은 학습 활동, 학교규칙, 교우관계, 교사관계이며 각 5 문항씩 4점 리커 트 척도로 응답하도록 구성되어있다. 학습활동은 학교에서 수 업이나 학습과 관련된 활동에 잘 참여하는지에 관련된 문항으 로 이루어져 있고, 학교규칙은 학교에서의 규칙을 잘 준수하 는지, 교우관계와 교사관계는 학교에서 친구나 교사와 좋은 관계를 형성하고 있는지 묻는 문항으로 이루어져 있다. 점수 가 높을수록 학교생활적응이 긍정적이라고 해석할 수 있도록 점수는 역산처리 하였다. 학교생활적응 척도의 신뢰도계수는 전체 .861 , 하위요인별로는 학습활동 .784, 학교규칙 .747 , 교 우관계.613, 교사관계 .788로 양호한 수준이었다. 


\section{자료분석}

수집된 자료의 통계적 분석을 위해 PASW 18 (SPSS Inc., Chicago, IL) 프로그램과 Mplus 7 (Muthén \& Muthén, 19982002) 프로그램을 사용하였다. 먼저, PASW 18 을 사용하여 연 구대상 청소년의 구성과 일반적인 특성에 대한 빈도와 백분율 을 구하였고, 청소년의 생활시간 활용에 대한 전반적 경향을 살펴보기 위하여 평균과 표준편차를 알아보았으며 주중과 주 말의 시간사용에 차이가 있는지 살펴보기 위해 paired t-test를 실시하였다. 자아인식과 학교생활적응 척도의 신뢰도를 검증 하기 위해서 Cronbach's $\alpha$ 를 계산하였다. 또한 집단별로 생활 시간 활용과 사회인구학적인 차이가 있는지 살펴보기 위해 교 차분석과 분산분석을 실시하였으며, 분산분석의 결과에서 각 집단에 따른 차이가 통계적으로 유의미한 경우에 사후검증으 로 Scheffé 검증을 실시하였다. 그리고 잠재프로파일 분석 결 과로 분류된 집단별로 자아인식과 학교생활적응에 차이가 있 는지 살펴보기 위하여 질병의 정도, 연간가구소득을 통제한 상태에서 다변량공분산분석(MANCOVA)를 실시하였다.

Mplus 7 프로그램은 청소년의 생활시간 활용 유형에 따 른 잠재프로파일분석을 위해 사용하였고, 데이터의 결측값 은 완전정보최대우도값(full information maximum likelihood [FIML])으로 추정하였다. 잠재프로파일분석은 군집분석과 마 찬가지로 비슷한 값을 갖는 집단을 분류하지만, 군집분석에 서는 연구자가 임의로 집단의 수를 결정하는 것과 달리 통계 적인 절차를 통해 집단의 수를 결정한다(Pastor, Barron, Miller, $\&$ Davis, 2007). 최종모형을 평가하여 집단의 수를 결정할 때 에는 통계처리과정을 통해 제시된 정보기준지수, 적합도 지 수, 분류의 질 등을 참고한다. 먼저 정보기준지수(Information Criterion Index)인 Akaike Information Criterion (AIC; Akaike, 1974)와 Bayesian Information Criterion (BIC; Schwarz, 1978) 를 살펴볼 수 있는데, $\mathrm{AIC}$ 와 $\mathrm{BIC}$ 의 값은 작아질수록 간명하 고 적합한 모형임을 의미한다(Nylund, Asparouhov, \& Muthén, 2007). 그렇지만 AIC와 BIC의 값은 잠재집단의 수가 증가할 수록 수치가 감소하는 경향이 있기 때문에 다른 적합도지수 도 함께 고려하여 잠재집단의 수를 결정해야 한다 (H.-J. Park, $\mathrm{Ha}, \&$ Park, 2011). 다른 적합도지수로 주로 Entropy값을 살 펴보는데, Entropy값은 개인을 특정한 잠재집단으로 분류하 는 것의 사후확률을 바탕으로 집단 구분의 정확도를 나타낸 다. Entropy값은 0부터 1 사이의 값을 가지는데, 각 개인이 완 벽하게 같은 집단으로 분류되면 1 의 값을 갖고 반대로 매번 다 른 집단에 분류될 경우에는 0 의 값을 가지기 때문에 1 에 가까
울수록 계층분류에 오류가 적다는 것을 의미하며(Muthén \& Muthén, 2000), 0.8이상이면 좋은 분류라고 평가한다(Clark, 2010). 또한 LMR (Lo-Mendell-Rubin)과 ALMR (adjusted-LoMendell-Rubin) 적합도 지수를 살펴볼 수 있는데, 이는 $\mathrm{k}$ 개의 집단을 가진 모형의 적합도가 $\mathrm{k}-1$ 개의 집단을 가진 모형에 비 해 나은지를 검증한다. 만약 LMR의 $p$-value가 유의하지 않으 면 집단이 $\mathrm{k}$ 개인 모형이 $\mathrm{k}-1$ 개 집단의 모형보다 더 낫다고 말 할 수 없다(Lo, Mendell, \& Rubin, 2001). 마지막으로 잠재집단 의 수를 결정하기 위해서는 모형적합지수뿐만 아니라 각 계층 의 유용성 역시 고려해야 한다. 즉, 각 잠재집단이 개인의 행동 변화를 유형화 하여 이해하는 것이 적절한지를 연구자가 고려 하여 판단해야 한다. 판단기준으로는 계층을 구성하는 개인의 수가 적절한지, 계층의 변화가 그래프상에서 잘 구분되는지, 다른 변수에 의해서 계층의 차이가 설명되는 것은 아닌지 등 을 고려하여 최적의 모형을 결정해야 한다(Muthén \& Muthén, 2000). 구체적으로 집단을 구성하는 개인의 수는 잠재계층분 류율을 통해 살펴볼 수 있는데, 각 계층의 분류율이 $1 \%$ 이하 로 나타나면 해당 분류는 실재적 유의성이 없으므로 각 계층 의 분류율이 $1 \%$ 이상이 되어야 한다는 기준이 있다(Jung \& Wickrama, 2008).

\section{연구결과}

\section{만성질환을 가진 청소년의 생활시간 활용 실태 (연구문제 1)}

만성질환을 가진 청소년의 생활시간 활용 실태는 Table 2 와 같 다. 생활시간 가운데 수면시간(주중: 357 분, 주말: 487 분)이 가 장 길고 독서시간(주중: 59분, 주말: 69분)이 가장 짧은 것으로 나타났다. 수면시간을 제외하고 주중에는 학원이나 과외로 보 내는 사교육 시간이 173 분으로 가장 많았고, 혼자 공부하는시 간(137분), TV시청이나 온라인게임과 같은 미디어 이용시간 (117분), 친구와 만나서 함께 보내는 시간(99분), 독서시간(44 분) 순으로 나타났다. 주말에는 미디어 이용시간(242분)이 가 장 길었고, 사교육 시간(235분), 혼자 공부하는 시간(119분), 친 구와 보내는 시간(112분), 독서시간(약 46분) 순으로 나타났다.

모든 생활시간은 주중과 주말에 차이가 나타났는데, 주말 에 할애하는 시간이 더욱 길게 나타났다. 이는 주중에는 학교 에서 생활하는 시간이 길기 때문에 주말에 비해 가용할 수 있 는 시간이 더 적기 때문으로 추정된다. 구체적으로, 수면시간 
Table 2

Time-Use of Adolescents with Chronic Diseases

\begin{tabular}{|c|c|c|c|c|c|}
\hline & & Min. & Max. & $M(S D)$ & $t$ \\
\hline \multirow[t]{2}{*}{ Sleep } & Weekdays & 180 & 570 & $357.27(71.65)$ & $-38.141^{* * *}$ \\
\hline & Weekend & 240 & 890 & $487.63(99.17)$ & \\
\hline \multirow[t]{2}{*}{ Private education } & Weekdays & 10 & 420 & $173.99(85.94)$ & $-8.586^{* * *}$ \\
\hline & Weekend & 30 & 720 & $235.26(128.32)$ & \\
\hline \multirow[t]{2}{*}{ Self study } & Weekdays & 10 & 480 & $137.27(85.44)$ & $-10.911^{* * *}$ \\
\hline & Weekend & 10 & 720 & $184.70(119.59)$ & \\
\hline \multirow[t]{2}{*}{ Reading } & Weekdays & 10 & 300 & $59.62(44.64)$ & $-7.183^{* * *}$ \\
\hline & Weekend & 10 & 300 & $69.88(46.76)$ & \\
\hline \multirow[t]{2}{*}{ Media use } & Weekdays & 1 & 480 & $117.65(83.56)$ & $-34.158^{* * *}$ \\
\hline & Weekend & 10 & 840 & $242.28(127.56)$ & \\
\hline \multirow[t]{2}{*}{ Meeting friends } & Weekdays & 1 & 480 & $99.18(73.59)$ & $-15.469^{* * *}$ \\
\hline & Weekend & 30 & 720 & $172.60(112.86)$ & \\
\hline
\end{tabular}

Note. $N=958$; Unit: Minutes.

${ }^{* * *} p<.001$.

은 주말이 주중에 비해 약 130 분 정도 길었고 $(t=-38.141, p<$ .001), 학원이나 과외로 보내는 사교육 시간은 주말에 약 61분 정도 길었다 $(t=-8.586, p<.001)$. 혼자 공부하는 시간은 주중 보다 주말에 약 47 분정도 더 할애하였고 $(t=-10.911, p<.001)$, 독서시간은 6 가지 생활시간 하위 영역 중 가장 적은 시간을 할 애하는 영역이었지만 주말이 약 10 분정도 길게 나타났다 $(t=$ -7.183, $p$ <.001). TV나 컴퓨터와 같은 미디어는 주말에 약 125 분 정도 더 사용하였으며 $(t=-34.158, p<.001)$, 마지막으로 친 구와 만나서 함께 노는 시간은 주말에 약 73 분정도 더 많은 것 $(t=-15.469, p<.001)$ 으로 나타났다.

\section{만성질환을 가진 청소년의 생활시간 활용 유 형에 따른 잠재프로파일의 구성과 생활시간 활용 실태 (연구문제 2)}

생활시간 활용을 기준으로 만성질환을 가진 청소년의 생활시 간 활용 유형을 잘 설명하는 잠재집단의 수를 결정하기 위하 여 다양한 적합도 지수를 비교하였다. 모형비교는 AIC, ABIC, Entropy, ALMR과 같은 적합도 지수를 사용하였고, 잠재집단 수가 2개인 모형부터 5개인 모형까지 적합도 지수를 비교하 였다. Table 3에 제시하였듯이 집단의 수가 2개인 모형부터 5 개인 모형으로 변화하면서 $\mathrm{AIC}$ 와 $\mathrm{BIC}$ 의 값이 지속적으로 감 소하는 것으로 나타났다. 그리고 모든 모형에서 잠재계층분류 율이 $1 \%$ 이상 되어야 한다는 기준 (Jung \& Wickrama, 2008)에 부합하였다. 다만 $\mathrm{k}$ 개 집단인 모형이 k-1개의 모형에 비해 유
의하게 좋은지를 나타내는 ALMR값을 살펴본 결과, 집단이 4 개에서 5 개로 변화할 때에는 ALMR의 우도비차이가 통계적 으로 유의미하지 않게 나타나 집단이 4 개인 모형이 5 개인 모 형에 비해 청소년의 생활시간 활용 유형을 더욱 잘 설명할 수 있다는 결과가 나왔다. 다양한 조건을 고려한 결과 최종적으 로 집단이 4 개인 모형을 채택하였고, Entropy역시 높은 수준 (Entropy $=0.804)$ 이었다.

최종적으로 도출된 네 잠재집단의 생활시간 활용 양상은 Figure 1 과 같다. 첫 번째 집단의 경우, 수면시간과 매체이용시 간이 다른 집단과 비교했을 때 가장 길고 사교육 공부시간, 개 인공부 시간이 가장 짧다. 두 번째 집단은 다른 집단에 비해 학 원과 과외로 보내는 시간이 가장 길다는 특징이 두드러지고, 세 번째 집단은 수면시간, 매체이용시간, 친구만남시간이 가 장 짧고 개인공부시간이 가장 길게 나타났다. 마지막으로 네 번째 집단은 독서시간과 친구만남시간이 다른 집단에 비해 길 게 나타났다. 이러한 생활시간 사용 패턴에 맞게 집단 1 은 '매 체중심 여가형(media using leisure type)', 집단 2 는 '사교육의존 학습형(private education dependant learning type)', 집단 3은 '자 율 학습형(self-study learning type)', 마지막으로 집단 4는 '균형 잡힌 여가형(balanced leisure type)'으로 명명하였다. 전체 질병 청소년 가운데 '사교육의존 학습형' 청소년이 $63.2 \%$ 로 가장 많았고, '매체중심 여가형' 청소년이 $15.6 \%$, '균형 잡힌 여가 형' 청소년이 $13.5 \%$, ‘자율 학습형' 청소년이 $7.7 \%$ 순이었다. 
Table 3

Fit Indices for the LPA Solutions

\begin{tabular}{|c|c|c|c|c|c|c|c|c|c|}
\hline \multirow[b]{2}{*}{ No. of classes } & \multirow[b]{2}{*}{ AIC } & \multirow[b]{2}{*}{$\mathrm{ABIC}$} & \multirow[b]{2}{*}{ Entropy } & \multirow[b]{2}{*}{ ALMR LR test $p$-value } & \multicolumn{5}{|c|}{$N(\%)$} \\
\hline & & & & & 1 & 2 & 3 & 4 & 5 \\
\hline 2 & 89308.165 & 89370.654 & 0.781 & 0.0000 & $\begin{array}{c}751 \\
(.78)\end{array}$ & $\begin{array}{c}207 \\
(.22)\end{array}$ & & & \\
\hline 3 & 88918.011 & 89002.455 & 0.797 & 0.0137 & $\begin{array}{c}687 \\
(.72)\end{array}$ & $\begin{array}{l}119 \\
(.12)\end{array}$ & $\begin{array}{l}152 \\
(.16)\end{array}$ & & \\
\hline 4 & 88628.091 & 88734.490 & 0.804 & 0.0001 & $\begin{array}{l}146 \\
(.15)\end{array}$ & $\begin{array}{l}629 \\
(.66)\end{array}$ & $\begin{array}{c}70 \\
(.07)\end{array}$ & $\begin{array}{l}113 \\
(.12)\end{array}$ & \\
\hline 5 & 88477.792 & 88606.147 & 0.804 & 0.2547 & $\begin{array}{c}136 \\
(.14)\end{array}$ & $\begin{array}{l}593 \\
(.62)\end{array}$ & $\begin{array}{c}69 \\
(.07)\end{array}$ & $\begin{array}{c}108 \\
(.11)\end{array}$ & $\begin{array}{c}52 \\
(.05)\end{array}$ \\
\hline
\end{tabular}

Note. $N=958$.

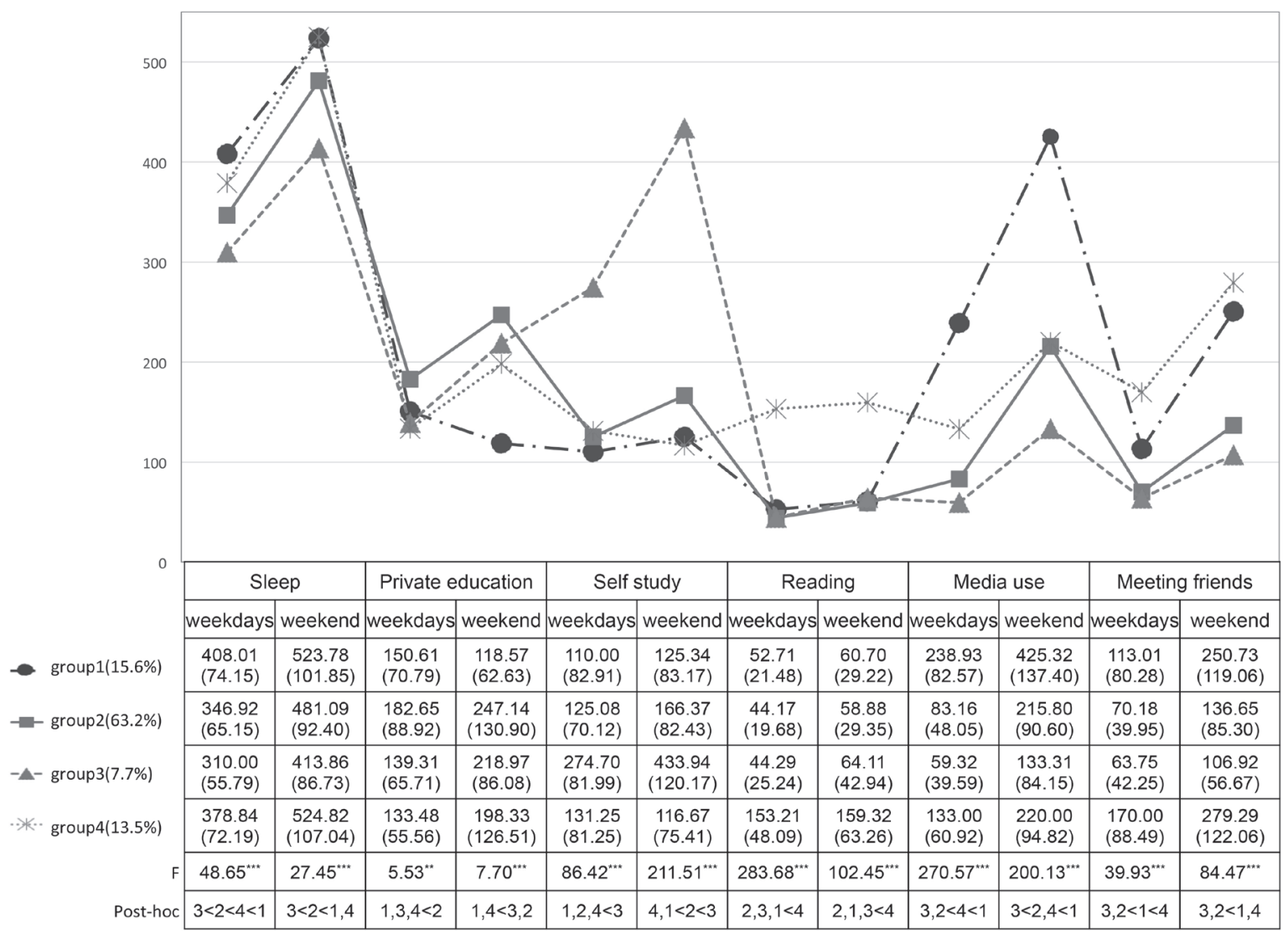

Figure 1. Time use profiles of adolescents with diseases

만성질환을 가진 청소년의 생활시간 활용 유 형에 따른 집단별 인구사회학적 특성 (연구문제3)

만성질환을 가진 청소년의 생활시간자료를 바탕으로 도출한 네 집단의 인구사회학적 차이가 있는지 살펴보기 위하여 성
별, 질병정도, 거주 지역, 가족형태, 부모의 맞벌이여부, 부모 의 직업수준에 따른 교차분석과 연간 가구소득의 분산분석을 실시하였다. 그 결과 청소년의 질병정도 $\left(\chi^{2}=17.093 p<.01\right)$, 거주 지역 $\left(\chi^{2}=14.390, p<.01\right)$, 가족형태 $\left(\chi^{2}=18.001, p<.01\right)$, 아버지의 직업수준 $\left(\chi^{2}=20.189, p<.01\right)$, 어머니의 직업수준 $\left(\chi^{2}=17.406, p<.01\right)$, 연간가구소득 $(F=16.474, p<.001)$ 에서 
Table 4

Sociodemographic Characteristics of Each Group by Time-Use Profiles

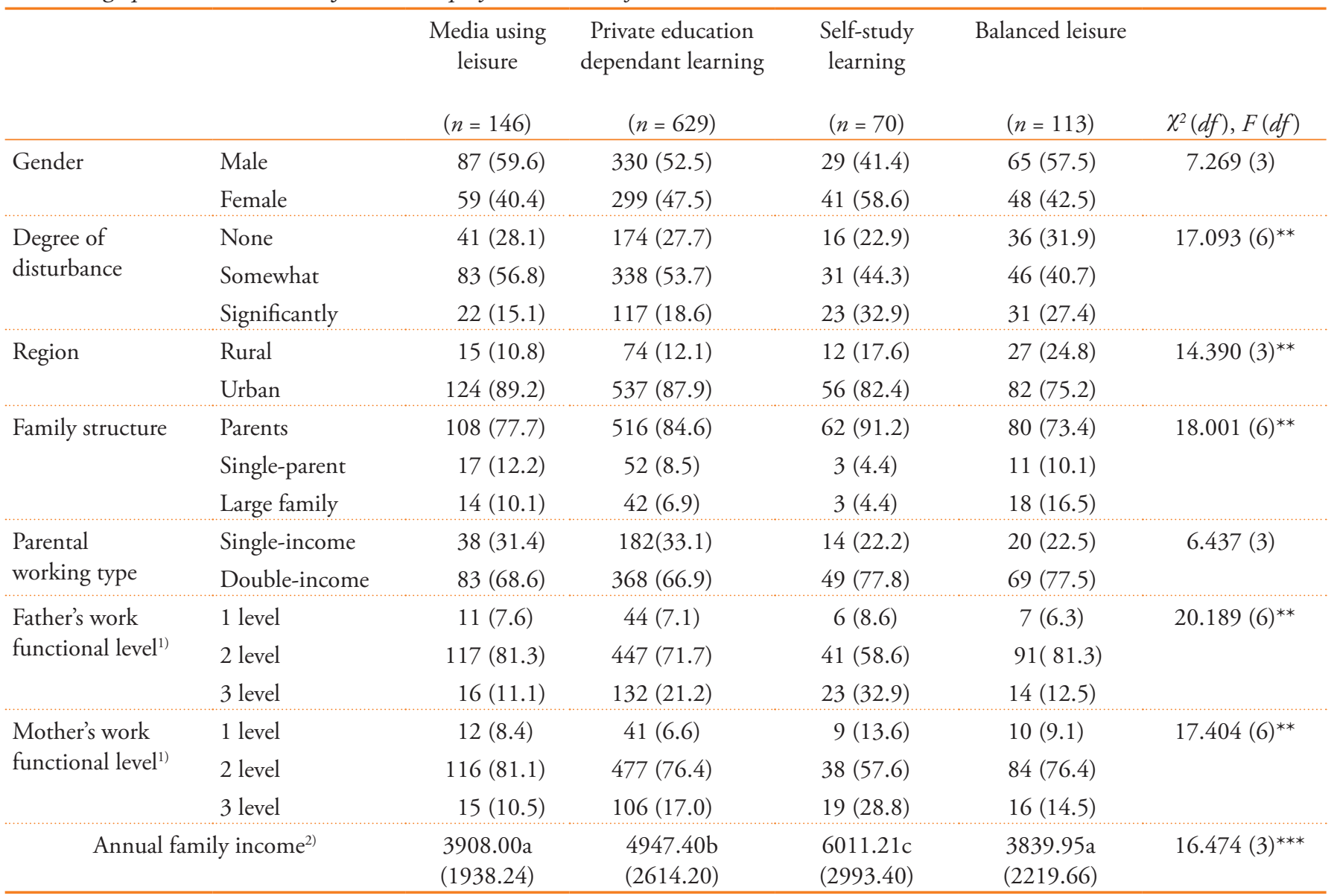

Note. Unit: $N(\%), M(S D) ;{ }^{1)}$ The functional level of jobs was re-categorized as proposed by the Korean standard classification of occupations, ${ }^{2)}$ unit: ten thousand won, a, b, c: post-hoc (sheffé).

${ }^{* *} p<.01 .{ }^{* * *} p<.001$.

통계적으로 유의한 차이가 나타났다.

구체적으로 살펴보면, '자율학습 형' 집단에 질병이 일상생 활이나 학교생활에 전혀 지장을 주지 않는다고 응답한 경증 청소년과 질병의 정도가 심각한 중증 청소년의 비율이 동시에 가장 높게 나타났다. 그리고 ‘자율학습 형' 집단을 제외하고 질 병의 정도가 심각한 중증 청소년의 비율이 높은 집단은 '균형 잡힌 여가형'이었는데, 이 집단 역시 독서시간이 길게 나타난 것으로 보아 질병의 중증도가 심한 청소년들은 주로 공부를 하거나 책을 읽는 등의 정적인 활동으로 많은 시간을 보내는 경향이 나타났다. 사는 지역에 따라서는 '자율 학습형'과 '균형 잡힌 여가형' 집단에 중소도시(읍/면)에 사는 청소년의 비율이 상대적으로 높았으며, '매체중심 여가형'과 '사교육의존 학습 형' 집단에 도시에 사는 청소년의 비율이 높게 나타났다. 가족 형태는 '사교육의존 학습형'과 ‘자율 학습형' 집단에 양부모와
함께 사는 청소년의 비율이 높았고, '매체중심 여가형'과 '균형 잡힌 여가형' 집단에는 한부모나 조부모가 함께 사는 청소년 의 비율이 높은 것으로 나타났다. 부모의 직업수준과 관련해 서는 '자율 학습형'을 제외한 세 집단에서는 주로 2직능에 종 사하는 부모님의 비율이 높은 반면에 '자율 학습형'에는 1직능 과 3직능 수준에서 일하는 아버지와 어머니를 가진 청소년의 비율이 다른 집단에 비해 높게 나타났다. 마지막으로 연간가 구소득은 '자율 학습형'이 가장 높고, ‘사교육의존 학습형', '매 체중심 여가형', ‘균형잡힌 여가형' 순으로 나타났다.

만성질환을 가진 청소년의 생활시간사용에 따라 분류한 집 단 별 인구사회학적 차이를 요약하면, 학습형(사교육 의존 학 습형, 자율 학습형)으로 분류된 청소년들은 양부모와 함께 살 며 비교적 안정적인 사회경제적 지위를 가지고 있는 것으로 나타났다. 
만성질환을 가진 청소년의 생활시간 활용 유 형에 따른 집단별 자아인식과 학교생활적응 의 차이 (연구문제 4 )

마지막으로 만성질환을 가진 청소년의 생활시간 활용 유형에 따른 집달별로 자아인식과 학교생활적응에 차이가 있는지 살 펴보았다. 연구문제 3 에서 네 집단별로 인구사회학적 차이가 있다는 것을 확인했기 때문에 이에 따른 효과를 통제할 필요 가 있다고 판단하여 공변량을 투입할 수 있는 다변량공분산분 석(MANCOVA)를 실시하였다. 공변량으로 질병정도와 연간 가구소득을 투입하였는데, 연간가구소득을 통제변수로 설정 한 이유는 집단별로 차이가 있었던 인구사회학적 변수인 사는 지역 $(r=.078, p<.05)$, 아버지의 직업지위 $(r=.217, p<.001)$, 어머니의 직업지위 $(r=.163, p<.001)$, 가족구조 $(r=-0210, p<$ .001)와 모두 상관관계가 높게 나타났기 때문이다.

우선 다변량공분산분석의 기본 가정인 종속변수의 공분산 행렬에 대한 동질성 여부를 확인하기 위해 Box's test 결과를 살펴보았고, 분산이 동질적인 것으로 나타났다 $(F=1.005, p=$ .467). 그리고 다변량공분산분석의 결과, 만성질환을 가진 청 소년의 생활시간 활용 유형에 따라 나눈 네 집단의 주효과는 통계적으로 유의하였으며(Pillai's Trace $=.112, p<.001$ ), Table 5 와 같이 자아정체감 $(F=3.988, p<.01)$, 진로정체감 $(F=4.585$, $p<.01)$, 그리고 학교생활적응의 네 하위영역인 학습활동 $(F=$ $27.044, p<.001)$, 학교규칙 $(F=7.279, p<.001)$, 교우관계 $(F=$ $4.019, p<.01)$, 교사관계 $(F=3.401, p<.05)$ 에서 통계적으로 유의한 차이가 있었다.

구체적으로 사후검정결과를 살펴보면 자아 인식의 하위
영역인 자아정체감은 '자율 학습형' 집단이 '매체중심 여가형' 과 '사교육의존 학습형'에 비해 유의하게 높았으며, 진로정체 감은 '자율 학습형'집단이 '매체중심 여가형'과 '균형 잡힌 여 가형'에 비해 높았다. 학교생활 적응의 하위영역인 학습영역 의 점수는 '매체중심 여가형'과 '균형잡힌 여가형'에 비해 '사 교육의존 학습형'이 약간 높고 '자율 학습형'이 가장 높은 것으 로 나타났다. 그리고 학교규칙, 교우관계에서는 '자율 학습형' 집단이 다른 세 집단에 비해 유의하게 높은 점수를 보였으며, 교사관계는 '자율 학습형' 집단이 '사교육의존 학습형'과 ‘균형 잡힌 여가형'에 비해 높았다.

\section{논의 및 결론}

이 연구는 만성질환을 가진 청소년의 생활시간 활용 유형에 따라 나눈 집단별로 자아인식과 학교생활적응에 차이가 있는 지 살펴보았다. 이를 위하여 KCYPS의 중 1 코호트 5차 년도 데 이터에서 청소년의 생활시간(취침시간, 사교육시간, 개인공 부시간, 독서시간, 매체이용시간, 친구만남 시간)을 활용하여 잠재프로파일분석을 하였다. 그리고 잠재프로파일분석을 통 해 도출된 집단별로 인구사회학적 특성을 살펴 본 후에 차이 가 있었던 질병정도와 가구소득을 통제하여 자아인식과 학교 생활적응에 차이가 있는지 살펴보았다. 주요 연구결과를 요약 하면 다음과 같다.

첫째, 만성질환을 가진 청소년들은 주중에는 주로 학업과 관련된 활동으로 가장 많은 시간을 보내고, 주말에는 사교육 을 통한 학습활동과 컴퓨터이용이나 TV시청과 같은 매체이

Table 5

Differences in Self-Perception and School Adjustment Among Time-use Profiles per Group

\begin{tabular}{|c|c|c|c|c|c|c|}
\hline & & $\begin{array}{l}\text { Media using } \\
\text { leisure } \\
(n=146)\end{array}$ & $\begin{array}{l}\text { Private education } \\
\text { dependant learning } \\
\qquad(n=629)\end{array}$ & $\begin{array}{l}\text { Self-study } \\
\text { learning } \\
(n=70)\end{array}$ & Balanced leisure & $F(d f)$ \\
\hline \multirow{3}{*}{$\begin{array}{l}\text { Self- } \\
\text { perception }\end{array}$} & Self-esteem & $2.96(.04)$ & $2.97(.02)$ & $3.05(.06)$ & $2.94(.04)$ & $.902(3)$ \\
\hline & Self-identity & $2.65(.03)^{\mathrm{a}}$ & $2.67(.02)^{\mathrm{a}}$ & $2.84(.05)^{\mathrm{b}}$ & $2.68(.04)^{\mathrm{ab}}$ & $3.988(3)^{* *}$ \\
\hline & Career-identity & $2.88(.05)^{\mathrm{a}}$ & $3.00(.02)^{\mathrm{ab}}$ & $3.19(.07)^{\mathrm{b}}$ & $2.93(.06)^{\mathrm{a}}$ & $4.585(3)^{* *}$ \\
\hline \multirow{3}{*}{$\begin{array}{l}\text { School } \\
\text { adjustment }\end{array}$} & Rules & $2.91(.04)^{\mathrm{a}}$ & $3.01(.02)^{\mathrm{a}}$ & $3.21(.06)^{\mathrm{b}}$ & $2.91(.05)^{\mathrm{a}}$ & $7.279(3)^{* * *}$ \\
\hline & Friendships & $3.10(.03)^{\mathrm{a}}$ & $3.16(.02)^{\mathrm{a}}$ & $3.29(.04)^{\mathrm{b}}$ & $3.14(.04)^{\mathrm{a}}$ & $4.019(3)^{* *}$ \\
\hline & Teacher & $2.90(.05)^{\mathrm{ab}}$ & $2.87(.02)^{\mathrm{a}}$ & $3.10(.07)^{\mathrm{b}}$ & $2.85(.06)^{\mathrm{a}}$ & $3.401(3)^{*}$ \\
\hline
\end{tabular}

Note. Covariance: diseases degree of disturbance and annual family income. a, b, c: post-hoc (Sheffé).

${ }^{*} p<.05 .{ }^{* *} p<.01 .{ }^{* * *} p<.001$. 
용으로 많은 시간을 보내는 것으로 나타났다. 이는 고등학교 에 다니는 청소년의 생활시간을 분석한 기존 연구들에서 사교 육으로 보내는 시간에 비해 스스로 공부하는 시간이 길게 나 타난 것과는 다른 결과(H.-J. Park et al. 2017; K. H. Kim \& Lee, 2006)로, 만성질환을 가진 청소년들 가운데 상당수가 학원이 나 과외로 보내는 사교육 시간이 꽤 긴 것으로 나타났다. 그리 고 주말에는 수면시간을 제외하고 미디어 이용시간이 가장 긴 것으로 나타났는데, 이는 청소년들이 여가시간에 신체활동 으로 보내는 시간이 점차 줄어들고 컴퓨터 게임으로 보내는 시간이 늘어나고 있다는 기존의 연구(Ha, 2017; K. H. Kim \& Lee, 2006)들과 같은 결과이다.

만성질환을 가진 청소년의 경우 질병으로 인한 수면부족과 만성피로로 인해 신체능력이 떨어지는 경향이 있어서 꾸준한 운동과 식이요법을 통해 건강관리를 해주어야 한다. 그리고 만성질환을 가진 청소년들에게 또래 관계는 정서적 지지를 제 공하는 중요한 보호요인(Stanton \& Revenson, 2011)이 되기 때 문에, 컴퓨터 게임이나 TV시청과 같은 활동으로 여가시간을 보내기 보다는 신체활동이나 친구들과 만나서 시간을 보낼 수 있도록 유도해야 한다. 즉, 만성질환 청소년이 보다 건강한 방 식으로 또래와 함께 여가시간을 보낼 수 있는 방안을 마련하 는 것이 필요하다.

둘째, 잠재프로파일분석 결과 만성질환을 가진 청소년의 생 활시간 활용 유형은 네 가지로 분류되었다. 네 가지 유형은 크 게 두 가지로 다시 구분할 수 있는데, 자신에게 주어진 시간을 학업이나 학습과 관련된 시간에 더 많이 할애하는 학습형과 여 가시간에 더 많은 시간을 사용하는 여가형이 있다. 학습형은 다시 학원이나 과외로 많은 시간을 보내는 '사교육의존 학습형 (private education dependant learning type)'과 개인공부시간이 길 게 나타난 '자율 학습형(self-study learning type'으로 분류되고, 여가형은 컴퓨터이용 시간이나 TV시청과 같은 매체이용 시간 이 긴 '매체중심 여가형(media using leisure type)'과 독서시간, 매 체이용시간, 친구만남 시간이 고르게 많았던 '균형 잡힌 여가 형(balanced leisure type)'으로 분류된다. 집단별 비율을 살펴보 면, '사교육의존 학습형' 에 분류된 청소년이 $63.2 \%$ 로 가장 많 았고, '매체중심 여가형'에 $15.6 \%$, '균형 잡힌 여가형'에 $13.5 \%$, 그리고 '자율 학습형'에 $7.7 \%$ 의 청소년이 분류되었다.

이 결과는 고등학교 3학년의 방과후 시간을 유형화 한 선 행연구(H.-J. Park et al., 2017)에서 여가활동으로 시간을 보내 는 청소년에 비해 학습활동을 하면서 시간을 보내는 청소년의 비율이 높게 나타난 것과 같은 결과이다. 만성질환청소년들의 생활시간 활용 유형이 일반청소년들과 크게 다르지 않다는 점
은 만성질환청소년들의 탄력성을 방증하는 것으로 해석할 수 있다. 하지만 일반청소년은 자기주도적으로 혼자 공부하면서 시간을 보내는 유형에 분류된 청소년의 비율이 사교육으로 시 간을 보내는 유형에 분류된 청소년에 비해 높게 나타난 것(H.J. Park et al., 2017)과 달리, 이 연구에서는 만성질환을 가진 상 당수의 청소년이 학원에 가거나 과외 활동을 하면서 많은 시 간을 보내는 것으로 나타났다.

셋째, 만성질환을 가진 청소년의 생활시간 활용 유형에 따라 나눈 집단별 인구사회학적 특성을 살펴본 결과 학습형으로 분 류된 청소년들이 양부모와 함께 살며 부모의 직업수준이 높고 연간가구소득이 높은 비교적 안정적인 사회경제적 지위를 갖 고 있는 것으로 나타났다. 이는 인구사회학적 특성이 시간활용 에 영향을 미친다고 밝힌 선행연구(Ha, 2017; Larson \& Verma, 1989; H.-J. Park et al., 2017; Y-J. Song, 2013)와 비슷한 결과이다.

잠재프로파일 분석 결과 나타난 시간사용의 네 가지 유형 가운데 어떠한 것이 더욱 바람직하다고 판단할 수는 없다. 즉, 학습형에 속한 청소년들이 여가형에 속한 청소년들에 비해 시 간활용을 잘 하고 있다고 말할 수도 없다. 하지만 학습형에 속 한 청소년들이 여가형에 속한 청소년들에 비해 비교적 안정적 인 사회경제적 지위를 갖고 있는 것은 학습형에 속한 질병청 소년들이 여가형에 속한 청소년들에 비해 긍정적인 지지체계 와 보호요인을 가지고 있다는 것을 의미한다. 특히 '자율학습 형' 집단에는 질병이 일상생활이나 학교생활에 전혀 지장을 주지 않는다고 응답한 경증 청소년과 질병이 주는 지장이 많 다고 응답한 중증 청소년의 비율이 동시에 높게 나타난 것으 로 보아 만성질환에서 비롯된 개인내적인 특성보다는 환경에 서 비롯된 외적인 특성들이 생활시간을 활용하는데 영향을 미 치는 것으로 해석할 수 있다. 즉, 비교적 안정적인 환경 속에서 생활하는 학습형 청소년들은 만성질환이라는 두드러지는 위 험요인을 가지고 있음에도 불구하고 학업을 위해 비교적 많은 시간을 할애하고 진로에 집중할 수 있는 것으로 분석된다.

넷째, 만성질환을 가진 청소년의 생활시간 활용 유형에 따 라 나눈 집단별 자아인식과 학교생활적응에 차이가 있는지 살 펴본 결과 '자율학습형'에 속한 청소년들이 다른 세 집단에 속 한 청소년들에 비해 자신에 대한 주관과 소신을 바탕으로 뚜 렷한 삶의 목표를 설정하고 미래에 하고 싶은 일을 결정하였 으며 학교생활에도 잘 적응하고 있는 것으로 나타났다. 생활 시간 활용 양상에 따라 자아인식과 학교생활적응에 차이가 있 다는 이러한 결과는 질병이 주는 어려움의 정도와 연간가구소 득에 따른 효과를 통제한 후에도 유의하게 나타난 결과이다. 즉, 만성질환청소년들의 자아인식과 학교생활적응에 영향을 
미칠 수 있을만한 인구사회학적 변수를 통제한 후에도 생활시 간을 어떻게 활용하는지에 따라 자아인식과 학교생활적응 수 준에 차이가 나타난다는 것을 의미한다. 자아탄력성은 자신이 속한 환경에서 발생하는 일상의 소소한 경험들로부터 발현된 다(Masten, 2001). Masten (2001)은 이를 일상의 마술(ordinary magic)이라고 표현하였는데, 이 연구에서도 만성질환청소년들 이 일상생활에서 어떻게 시간을 보내며 어떤 경험을 하는지가 탄력성의 자원으로 작용할 수 있다는 것을 확인할 수 있었다.

앞서 언급했듯이 청소년들이 어떤 활동을 하면서 시간을 보내는지에 대해 옳고 그름을 평가할 수는 없다. 하지만 학업 과 관련된 활동에 많은 시간을 할애하는 만성질환청소년들이 여가활동을 많이 하는 만성질환청소년들에 비해 안정적으로 자아정체감과 진로정체감을 확립하고 학교생활에 잘 적응한 다는 이러한 결과는, 청소년기에 이루어야 할 과업을 달성하 는데 어려움을 가진 만성질환청소년들이 학업보다는 여가활 동으로 시간을 많이 보내고 있다는 방증이다. 따라서 여가활 동으로 많은 시간을 보내는 만성질환청소년들을 비난하거나 억지로 학업에 관련된 활동에 참여시키기 보다는, 그들이 자 신에 대해 긍정적으로 인식하고 미래에 대한 목표를 세울 수 있도록 다양한 기회를 제공할 필요가 있다. 자신에 대해 긍정 적으로 평가하고 분명한 삶의 목적이나 의미를 갖는 것은 자 아탄력성을 촉진시키는 보호요인이 된다(Albrecht \& Devlieger, 1998; B. Lee, Park, \& Lee, 2013). 자아탄력성이 높은 만성질환 청소년은 그렇지 않은 청소년에 비해 질병에 대한 태도가 비 교적 긍정적이고 질병을 잘 관리하며, 자존감이 높고 좋은 또 래관계를 유지하는 것으로 나타난다(Jaser \& White, 2011; B. Lee, Park, \& Lee, 2013; Yi-Frazier et al., 2010). 따라서 만성질환 을 가지고 있는 청소년들이 자아정체감과 진로정체감 등을 잘 형성할 수 있도록 돕는다면, 그들이 질병을 더욱 잘 통제하고 타인과 긍정적으로 상호작용하며 심리사회적인 건강을 유지 할 수 있을 것이다(Jaser \& White, 2011; Yi-Frazier, et al., 2010).

청소년의 발달은 개인과 개인을 둘러싼 다양한 층위의 환경 간의 상호작용을 통해 이루어진다(Bronfenbrenner \& Morris, 1998). 그 중에서도 가정환경은 청소년의 건강한 성장 과 발달에 많은 영향을 미치는 환경이며, 가정에서 부모와의 맺는 관계는 청소년의 행동과 적응 방식에 결정적인 영향을 미친다(Granic, Dishion, \& Hollenstein, 2003). 이 연구에서도 비교적 안정적인 가정환경 속에서 생활하는 만성질환청소년 들이 만성질환이라는 두드러지는 위험요인을 가지고 있음에 도 불구하고 학업을 위해 비교적 많은 시간을 할애하고 진로에 집중할 수 있으며 이는 결국 청소년기에 달성해야 할 긍정적인
발달과업에도 영향을 미친다는 것을 확인하였다. 청소년 개인 이 가진 강점과 탄력성이 발휘되기 위해서는 청소년이 속한 맥 락에 가용할 만한 자원이 있거나 의미 있는 타인으로부터 지지 를 받았을 때 발휘되고 촉진될 수 있다(Lerner \& Benson, 2003). 만성질환청소년이 있는 가족은 치료에 따르는 경제적인 부 담, 부모의 높은 양육스트레스나 우울 등의 문제를 경험한다 고 알려져 있지만(Klinnert, Gavin, Wamboldt, \& Mrazek, 1992; Quittner, Opipari, Regoli, Jcobsen, \& Eigen, 1992) 만성질환을 가 진 청소년이 부모와 어떠한 관계를 맺고 어떻게 상호작용하느 냐에 따라 발달 및 심리사회적 적응에 큰 차이가 나타날 수 있 다(Florian \& Elad, 1998). 따라서 만성질환청소년의 탄력성을 증진시키고 긍정적인 발달을 돕기 위해서는 청소년 개인뿐만 아니라 가족을 대상으로 개입하는 노력이 필요하다.

마지막으로, 이 연구의 의의를 밝히고 연구의 제한점과 함 께 후속연구를 위한 제언을 하고자 한다. 이 연구의 의의는 첫 째, 만성질환청소년의 생활시간활용에 대해 사람중심 분석방 법인 잠재프로파일분석을 도입하였다는 점에서 방법론적 의 의가 있다. 기존연구들에서 수면시간, 게임이용시간, 사교육 시간 등과 같이 특정한 활동에 대한 시간을 집중적으로 분석 한 것과 달리 이 연구에서는 다양한 활동을 통합적으로 살펴보 고, 생활시간활용 유형에 따라 집단을 분류하였다. 특히 만성 질환청소년들이 가진 개인 내· 외적 특성들에 따라 각기 다른 생활패턴을 보인다는 것을 확인하고 그것이 발달과업을 달성 하는데 영향을 미친다는 것을 확인하였다. 이러한 결과는 청소 년의 긍정발달(PYD) 관점에서 만성질환청소년들의 일상경험 이 탄력성으로 작용할 수 있음을 확인했다는 점에서 의의가 있 다. 둘째, 만성질환청소년을 위한 개입 방안을 마련할 때에는 청소년의 개인뿐만 아니라 그 맥락을 함께 고려해야 한다는 점 을 밝혀 교육적 함의를 도출하였다. 연구 결과, 학업과 관련된 활동에 많은 시간을 할애하는 만성질환청소년들이 여가활동 을 많이 하는 청소년들에 비해 비교적 안정적으로 자아정체감 과 진로정체감을 확립하고 학교생활에도 잘 적응하는 것으로 나타났다. 하지만 이는 만성질환청소년들이 학업과 관련된 활 동으로 많은 시간을 보내야 발달과업을 이룰 수 있다는 것을 의미하지 않는다. 학업과 관련된 활동으로 시간을 많이 보내는 청소년들이 비교적 안정적인 사회경제적 지위를 가지고 있는 것으로 나타났는데, 이는 긍정적인 지지체계와 환경적인 보호 요인을 많이 가진 청소년일수록 만성질환이라는 위험요인으 로부터 발생하는 부정적인 영향을 완충시키고 건강하게 발달 할 수 있다는 것을 의미한다. 따라서 만성질환청소년이 강점과 탄력성을 발휘할 수 있도록 청소년 개인뿐만 아니라 청소년이 
속한 맥락을 함께 고려하여 개입계획을 마련할 필요가 있다. 하지만 이 연구에서는 만성질환을 가진 청소년의 적응과 발달 에 영향을 미칠 수 있는 다양한 환경과 맥락을 고려하지 못했 다는 점에서 한계가 있다. 선행연구를 통해 만성질환청소년의 생활시간 활용 유형에 영향을 미칠 수 있을만한 인구사회학적 변인을 탐색하고 차이가 있었던 변수들을 통제변인으로 설정 하였지만, 주로 변화하지 않거나 쉽게 바뀌지 않는 특성을 가 진 변수들을 중심으로 살펴보았다. 그리고 안정적인 가정환경 이 만성질환청소년의 보호요인이 될 수 있다는 결론을 이끌어 냈지만, 구체적으로 만성질환청소년의 건강한 발달과 적응을 도울 수 있는 가정환경을 조성하기 위해서 어떠한 개입을 할 수 있는지 실천적인 함의를 도출하지 못했다. 따라서 후속연구 에서는 만성질환 청소년의 가족관련 변수나 부모자녀관계에 대한 변수를 고려하여 연구를 진행한다면, 실천적인 함의까지 도출할 수 있는 좋은 연구가 될 수 있을 것이다.

\section{Acknowledgements}

This study was supported by the BK21 plus Program of National Research Foundation of Korea Grant funded by the Korean Government (NRF-22B20152813529).

\section{Conflict of Interest}

No potential conflict of interest relevant to this article was reported.

\section{References}

\section{In English}

Akaike, H. (1974). A new look at the statistical model identification. IEEE Transactions on Automatic Control, 19(6), 716-723. doi:10.1109/TAC.1974.1100705

Albrecht, G. L., \& Devlieger, P. J. (1998). The disability paradox: High quality of life against all odds. Social Science and Medicine. 48(8), 977-988. doi:10.1016/S02779536(98)00411-0

Atkin, K., \& Ahmad, W. I. U. (2001). Living a 'normal' life: Young people coping with thalassaemia major or sickle cell disorder. Social Science \& Medicine, 53(5), 615-626. doi:10.1016/S0277-9536(00)00364-6
Barlow, J. H., \& Ellard, D. R. (2006). The psychosocial wellbeing of children with chronic disease, their parents and siblings: An overview of the research evidence base. Child: Care, Health and Development, 32(1), 19-31. doi:10.1111/ j.1365-2214.2006.00591

Bergman, L. R., \& Magnusson, D. (1997). A person-oriented approach in research on developmental psychopathology. Development and psychopathology, 9(2), 291-319. doi: 10.1017/S095457949700206X

Blaiss, M. S. (2008). Pediatric allergic rhinitis: Physical and mental complications. Allergy and Asthma Proceedings, 29(1), 1-6. doi:10.2500/aap2008.29.3072.

Bronfenbrenner, U., \& Morris, P. A. (1998). The ecology of developmental processes. In W. Damon \& R. M. Lerner (Eds.), Handbook of child psychology: Theoretical models of human development (pp. 993-1028). Hoboken, NJ: John Wiley \& Sons Inc.

Clark, S. L. (2010). Mixture modeling with behavioral data. Los Angeles, CA: University of California.

Cowen, E. L., \& Kilmer, R. P. (2002). "Positive psychology": Some plusses and some open issues. Journal of Community Psychology, 30(4), 449-460. doi:10.1002/jcop. 10014

Eiser, C. (1990). Psychological effects of chronic disease. Journal of Child Psychology and Psychiatry, 31(1), 85-98. doi:10.1111/ j.1469-7610.1990.tb02274.x

Erikson, E. H. (1968). Identity: Youth and crisis. New York: Norton.

Fergus, S., \& Zimmerman, M. A. (2005). Adolescent resilience: A framework for understanding healthy development in the face of risk. Annual Review of Public Health, 26(1), 399419. doi:10.1146/annurev.publhealth.26.021304.144357

Florian, V., \& Elad, D. (1998). The impact of mother's sense of empowerment on the metabolic control of their children with juvenile diabetes. Journal of Pediatric Psychology, 23(4), 239-247. doi:10.1093/jpepsy/23.4.239

Granic, I., Dishion, T. J., \& Hollenstein, T. (2003). The family ecology of adolescence: A dynamic systems perspective on normative development. In G. R. Adams, \& M. D. Berzonsky (Eds.), Blackwell handbook of adolescence (pp. 60-91). Malden, MA: Blackwell Publishing. doi:10.1002/9780470756607.ch4

Greenberg, H. S., Kazak, A. E., \& Meadows, A. (1989). Psychological functioning in 8- to 16-year-old cancer survivors and their parents. The Journal of Pediatrics, 114(3), 488-493. doi:10.1016/S0022-3476(89)80581-5

Guerra, N. G., \& Bradshaw, C. P. (2008). Linking the prevention of problem behaviors and positive youth development: Core competencies for positive youth development and risk prevention. New Directions for Child and Adolescent Development, 122, 1-17. doi:10.1002/cd.225 
Hatherill, S. (2007). Psychiatric aspects of chronic physical illness in adolescence: Significant numbers of chronically ill adolescents have problems coping with their illness. Continuing Medical Education, 25(5), 212-214.

Hofferth, S. L., \& Sandberg, J. F. (2001). How American children spend their time. Journal of Marriage and Family, 63(2), 295-308. doi:10.1111/j.1741-3737.2001.00295.x

Jaser, S. S., \& White, L. E. (2011). Coping and resilience in adolescents with type 1 diabetes. Child: Care, Health and Development, 37(3), 335-342. doi:10.1111/j.13652214.2010.01184.x

Jenson, J. M., \& Fraser, M. W. (2015). Social policy for children and families: A risk and resilience perspective. Thousand Oaks, CA: Sage Publication.

Jung, T., \& Wickrama, K. A. S. (2008). An introduction to latent class growth analysis and growth mixture modeling. Social and Personality Psychology Compass, 2(1), 302-317. doi:10.1111/j.1751-9004.2007.00054.x

King, G., McDougall, J., DeWit, D., Hong, S., Miller, L., Offord, D., . . . LaPorta, J. (2005). Pathways to children's academic performance and prosocial behaviour: Roles of physical health status, environmental, family, and child factors. International Journal of Disability, Development and Education, 52(4), 313-344. doi:10.1080/10349120500348680

Klinnert, M. D., Gavin, L. A., Wamboldt, F. S., \& Mrazek, D. A. (1992). Marriages with children at medical risk: The transition to parenthood. Journal of the American Academy of Child \& Adolescent Psychiatry, 31(2), 334.342. doi:10.1097/00004583-199203000-00023

La Greca, A. M. (1990). Social consequences of pediatric conditions: Fertile area for future investigation and intervention?. Journal of Pediatric Psychology, 15(3), 285307. doi:10.1093/jpepsy/15.3.285

Larson, R. W., \& Verma, S. (1999). How children and adolescents spend time across the world: work, play, and developmental opportunities. Psychological Bulletin, 125(6), 701-736. doi:10.1037/0033-2909.125.6.701

Larson, R. W. (2000). Toward a psychology of positive youth development. American Psychologist, 55(1), 170-183. doi:10.1037//0003-066X.55.1.170

Lavigne, J. V., \& Faier-Routman, J. (1992). Psychological adjustment to pediatric physical disorders: A meta-analytic review. Journal of Pediatric Psychology, 17(2), 133-157. doi:10.1093/jpepsy/17.2.133

Lerner, R. M., Brentano, C., Dowling, E. M., \& Anderson, P. M. (2002). Positive youth development: Thriving as the basis of personhood and civil society. New Directions for Student Leadership, 95, 11-34. doi:10.1002/yd.14

Lerner, R. M., \& Benson, P. I. (2003). Developmental assets and asset-building communities: Implications for research, policy, and practice. New York: Kluwer Academic/Plenum.

Lo, Y., Mendell, N. R., \& Rubin, D. B. (2001). Testing the number of components in a normal mixture. Biometrika, 88(3), 767-778.

Masten, A. S. (2001). Ordinary magic: Resilience processes in development. American Psychologist, 56(3), 227. doi:10.1037/0003-066X.56.3.227

Mplus (Version 6.11). [Computer software]. Los Angeles, CA: Muthén \& Muthén.

Muthén, B. \& Muthén, L. K. (2000). Integrating person-centered and variable-centered analysis: Growth mixture modeling with latent trajectory classes. Alcoholism: Clinical and Experimental Research, 24(6), 882-891. doi:10.1111/ j.1530-0277.2000.tb02070.x

Nylund, K. L., Asparouhov, T., \& Muthén, B. O. (2007). Deciding on the number of classes in latent class analysis and growth mixture modeling: A Monte Carlo simulation study. Structural Equation Modeling, 14(4), 535-569. doi:10.1080/10705510701575396

Pastor, D. A., Barron, K. E., Miller, B. J., \& Davis, S. L. (2007). A latent profile analysis of college students' achievement goal orientation. Contemporary Educational Psychology, 32(1), 8-47. doi:10.1016/j.cedpsych.2006.10.003

Quittner, A. L., Opipari, L. C., Regoli, M. J., Jcobsen, J., \& Eigen, H. (1992). The impact of caregiving and role strain on family life: Comparisons between mothers of children with cystic fibrosis and matched controls. Rehabilitation Psychology, 37(4), 275-290. doi:10.1037/h0079107

Rhee, H., Wenzel, J., \& Steeves, R. H. (2007). Adolescents' psychosocial experiences living with asthma: A focus group study. Journal of Pediatric Health Care 21(2), 99-107. doi:10.1016/j.pedhc.2006.04.005

Roder, I., \& Boekaerts, M. (1999). Stress, coping, and adjustment in children with a chronic disease: A review of the literature. Disability and Rehabilitation, 21(7), 311-337. doi:10.1080/096382899297576

Rosenberg, M. (1965). Society and the adolescent self-image. Princeton, NJ: Princeton University Press.

Schwarz, G. (1978). Estimating the dimension of a model. The Annals of Statistics, 6(2), 461-464. doi:10.1214/ aos/1176344136

Shiu, S. (2001). Issues in the education of students with chronic illness. International Journal of Disability, Development and Education, 48(3), 269-281. doi:10.1080/10349120120073412

Spratling, R., \& Weaver, S. R. (2012). Theoretical perspective: Resilience in medically fragile adolescents. Research and Theory for Nursing Practice, 26(1), 54-68. doi:10.1891/15416577.26.1.54

Stanton, A., \& Revenson, T. A. (2011). Adjustment to chronic disease: Progress and promise in research. In H. S. Friedman, 
\& R. C. Silver (Eds.). Foundations of health psychology (pp. 241-268). New York: Oxford University Press.

Suris, J.-C., Michaud, P.-A., \& Viner, R. (2004). The adolescent with a chronic condition. Part I: Developmental issues. Archives of Disease in Childhood, 89(10), 938-942. doi:10.1136/adc.2003.045369

Taylor, R. M., Gibson, F., \& Franck, L. S. (2008). The experience of living with a chronic illness during adolescence: A critical review of the literature. Journal of Clinical Nursing, 17(23), 3083-3091. doi:10.1111/j.1365-2702.2008.02629.x

Yi-Frazier, J. P., Smith, R. E., Vitaliano, P. P., Yi, J. C., Mai, S., Hillman, M.,\& Weinger, K. (2010). A person-focused analysis of resilience resources and coping in diabetes patients. Stress Health, 26(1), 51-60. doi:10.1002/smi.1258

Zick, C. D. (2010). The shifting balance of adolescent time use. Youth \& Society, 41(4), 569-596. doi:10.1177/0044118X09338506

\section{In Korean}

Chin, M.-J. (2008). Family structure and children's time use. Family and Culture, 20(3), 187-211.

Ha, M.-S. (2017). The relationship between the trajectory of a life time of adolescents, family environment and emotional behavioral problems. Korean Journal of Youth Studies, 24(3), 25-59. doi:10.21509/KJYS.2017.03.24.3.25

Kim, K. H. \& Lee, K. S. (2006). Cheongsonyeon saenghwalsigan hwaryongsiltae mit byeonhwa[청소년 생활시간 활용실태 및 변화]. (Report No. 06-R14). Seoul: Korea Institute for Youth Development.

Kim, S. J. \& Chung, I.-J. (2016). The effect of sleep duration on youth school adjustment mediated by parenting behavior. Korean Journal of Child Studies, 37(3), 13-26. doi:10.5723/ kjcs.2016.37.3.13

Kong, I.-K. (2008). Effects of Holland's Career Exploration Program on career maturity, career efficacy, career identity and career barriers of underachievers (Doctoral dissertation). Retrieved from http://www.riss.kr/link?id=T11297361

Lee, B., Park, H. J., \& Lee, K. (2013). Korean adolescents' physical health and peer relationships: The mediating effects of self-perceived health status and resilience. Korean Journal of Child Studies, 34(5), 127-144. doi:10.5723/ KJCS.2013.34.5.127

Lee, H., Son, S., \& Hong, S. (2018). Testing the autoregressive cross-lagged effects between adolescents' life satisfaction, school learning activities and friendship: Multigroup analysis across gender. Studies on Korean Youth, 29(1), 209238. doi:10.14816/sky.2018.29.1.209

Lee, J., Kang, J., Rhie, S., \& Chae, K. Y. (2013) Impact of sleep duration on emotional status in adolescents. Journal of the Korean Child Neurology Society, 21(3), 100-110.

Min, B. S. (1991). The effect of school adaptation and self-concept on academic performance (Unpublished master's thesis). Hongik University, Seoul, Korea.

Park, H. (2015). Effect of sleep duration on suicidal ideation in Korean adolescents. The Journal of the Korean Society of School Health, 28(1), 1-9. doi:10.15434/kssh.2015.28.1.1

Park, H.-J., Ha. Y., Park, M.-H. (2011). Application of the mixture modeling to the student characteristics and reading achievement according to the patterns of the patterns of ICT use. Journal of Korean Society for Educational Evaluation, 24(3), 733-754.

Park, H.-J., Son, Y.-H., \& Kim, J. (2017). An analysis of afterschool time use patterns among the third graders in high school. Studies on Korean Youth. 28(2), 197-224. doi:10.14816/sky.2017.28.2.197

Ryou, B. (2017). Relationship between time availability and time invested in leisure activities in adolescents. Journal of the Korean Society of Child Welfare, 60, 25-57. doi:10.24300/ JKSC.2017.12.60.25

Ryu, S. \& Jeong, E. (2001). A study on the influences of games in youth - focusing on the heavy users. Studies on Korean Youth, 12(2), 35-64.

Song, J., Jon, D.-I., Soek. J. H., Hong, N. Kim, Y. S., \& Hong, H. J. (2010). Gender differences of externalizing and internalizing behavior problems according to the extracurricular education. Journal of Korean Academy of Child and Adolescent Psychiatry, 21(1), 37-44.

Song, Y.-J. (2013). Differences in time use of adolescent by parental socioeconomic characteristics. Family and Culture, 25(3), 31-53.

Song, H.-O. (2008). A structural analysis of the variables related to adolescents's ego-identity. (Doctoral dissertation) Retrieved from http://www.riss.kr/link?id=T11598966

Korea Centers for Disease Control and Prevention. (2017). Korea Youth Risk Web-based Survey. Retrieved from KCDC website: http://www.cdc.go.kr/

\section{ORCID}

Boram Lee http://orcid.org/0000-0003-1569-4415

Received April 30, 2018

Revision received June 22, 2018

Accepted July 30, 2018 